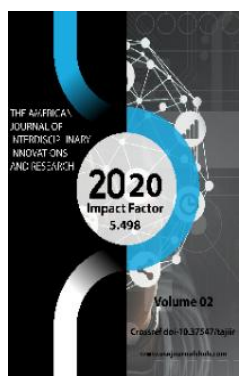

\title{
Oxymoron - A Semantic Contradiction
}

Saminov Abdumalik

PhD student of Fergana State University, Uzbekistan

Journal Website: http://usajournalshub.c om/index,php/tajiir

Copyright: Original content from this work may be used under the terms of the creative commons attributes 4.0 licence.

\section{ABSTRACT}

Speakers differ from each other in the selection and use of linguistic tools in the process of interaction in all contexts and in all areas of their speech activities. A choice of language means within a common language leads to the emergence of different speech appearances in speech. As a result, speech styles are formed in different forms.

\section{KEYWORDS}

Oxymoron, contradiction, semantic contradiction speech.

\section{INTRODUCTION}

In speech, there are specific rules by which words are connected to each other to form a syntactic construction. However, these rules are not always followed as "it is not enough to know the exact meaning of words to use them correctly." (Abdurakhmonov, 1981). There are phenomena in language in which words are used in context in a figurative sense that is radically different from their lexical meaning. Especially, the use of words in their lexical meanings is not sufficient to reveal the nuances and different semantic aspects of thought in the context. In this regard, it is essential to know the laws of association of each word with another, the possibility of combining words through different modal meanings. Each component that makes up the syntactic construction of a combination - each word has its own unique potential and is unique in different words. 


\section{MATERIALS AND METHODS}

The literary style is unique. Individuality rises to a higher level in the literary text. The writer uses unique techniques, types of movement to influence the psyche of the listener and the reader, to encourage him to think, to expand the scope of imagination and to increase the emotional sensitivity of speech in his work. This speech has specific purposes:

- To attract the listener's attention;

- Increase the interest of the audience;

- To ensure the accuracy of linguistic arguments proofs in speech;

- The use of unusual syntactic forms in the figurative expression of thought;

- Increase the effectiveness of speech.

One of the syntactic-stylistic means of expressing individuality in a literary text is the oxymoron. The term "oxymoron" is studied in the form of "oxymoron" or "oxymoron". The term is defined in the scientific literature and dictionaries as follows:

"Oxymoron"(Greek"Oxymoron" - intelligent, ignorant) - a way to exaggerate the object of the image by juxtaposing words which represents two opposite concepts (Boboyev, 2002).

"Oxymoron" (Greek "Oxymoron" - a clever but meaningless) - a methodical figure consisting of the reciprocal addition of two opposing concepts (two words with opposite meanings) that logically negate each other (Hojiyev, 2002).

\section{RESULTS AND DISCUSSIONS}

This methodological tool which enhances the effectiveness of the literary text is a syntactic construction formed as a result of a combination of illogically contradictory concepts. The oxymoron is basically built on a logical contradiction and ensures the discovery of new, unique meanings, the effective expression of a sentence or sentence, i.e. an idea. Even the combination of all opposite words does not produce an oxymoron. The artistic thinking of the speaker or writer plays a key role in this process. In expressing his purpose, the poet or writer approaches the seemingly illogical connection of lexical means from an artistic and aesthetic point of view, resulting in the phenomenon of "oxymoron". For example:

Tongda ot etaklab o'tib borar kim,

Qop-qora olovday lovillar yo'llari.

Kampirlar alanglab quloq soladi jim,

Bir seskanib ketdi nuroniy cholar. (Sh.Rahmon, 2012)

Eng baxtiyor lahzalarda ham

Uning sokin isyoni so'nmas.

Tugilmagan shunchaki aslo,

U xech kachon shunchaki o'Imas. (Sh.Rahmon, 2012)

Sokin isyon (Silent rebellion) ... these two words do not actually boil in the same pot silence denies rebellion, rebellion denies silence. It's as if they don't get along at all. But those who know Shavkat Rahmon personally, those who know him intimately, see that these two negative situations are perfectly combined in his personality, they get along well with each other. This quiet rebellion of 
the poet does not end not only in mothers who are sad or angry, but also

“Eng baxtiyor lag/zalarda ham so'nmaydi" in the happiest moments. (Sh.Rahmon, 2012)

Odam uhlayapti,

Uyg'otmang uni!

\section{Suknat shivirlari kuloqlariga ...}

Odam lablarini tatar sevib

Bolalikning barcha

Buloqlarga. (Sh.Rahmon, 2012)

The poet reveals the subtle aspects of meaning, using special pictorial means in these poetic verses. In other words, although "suknat-silence" means quietness, the word "whispers" is used in the sense of making a sound, expressing a certain form of sound. The poet used words that contradicted these two meanings. It is a syntactic unit formed in a unique way.

A poet who shows the artistic imagery or aspires to novelty uses an oxymoron to reveal different semantic aspects of lexemes in expressing his thoughts. For example: qayg'uli shodlik (sad -joy), qo'ra chaqmoq (black lightning), kop-qo'ra olov (black fire), jodugar navo, (witch melody). These syntactic combinations differ from the usual phrases in that they capture the listener's attention, highlighting the lyrical protagonist's purpose in a more complete and unique way.

The oxymoron method can occur in order to express a meaning, concept, or idea in a new way: soqov-qichqiriq (a dumb-shout). This compound served to express meanings such as pain, suffering, understanding the cry within a person.

Ironic content also forms an oxymoron by expression. For example: soda-mug'ombir (naïve-swindler), aqlli jinni (clever-mad). With the help of simple, insane lexemes in these constructions, in order to create an ironic content that logically contradicts their meaning, mug'ombir-aqlli (the sly- clever) words are combined to express a situation contrary to the ideal or purpose of the speaker, and thus an unusual connection is formed.

While illogicality is the main theory in the emergence of the oxymoron method, the main factors that create an oxymoron are such as the speaker's boredom with traditional means of expression or his desire to express new content through a new form and try to focus on unity of speech.

The creative artistic and aesthetic goal also plays a leading role in the creation of the oxymoron. Especially poets like Federica Garcia Lorca, Rauf Parfi can find a lot of oxymorons, which are the product of creative artistic thinking. "Qayg'uli shodlik" (Sad Joy) (Lorca), "Mendan tilsizgina bir narsa so'rar" (He asks me for something without a tongue) (A poem entitled "Chingiz Aitmatov" by R. Parfi, p.182.), “Kibor olamon” (Arrogant crowd) (a poem entitled "Van Gogh" by R. Parfi, p. 179). In these examples, the reader should seek to understand why the author used such combinations. As a result, the text is reconstructed in the reader's perception. In the context of extra-textual text, it is possible and necessary at the level of thinking, as the oxymoron is both thinking and a speech phenomenon at the same time. They are 
inseparable. On the one hand, it takes on a figurative tone; on the other hand, the scope of meaning expands. As a result, the unity of form and content of the sentence is perfected. At this point, another problem arises. In the examples given, the oxymoron method sometimes occurs with the help of two words, while in another it is formed within a metaphor or sentence. This means that oxymoron can be formed in different forms.

In some sources, including in the work of $M$. Yuldashev, oxymoron is given as an antithesis. We cannot agree with this opinion. At first glance, oxymoron looks like an antithesis, however it has different aspects. We think we need to find the fine point where they connect and mark their different sides.

\section{CONCLUSION}

In conclusion, oxymoron is not only a product of conflict. Perhaps semantic contradiction is a comprehensive syntactic-stylistic tool that manifests itself as a product of artistic thinking, with its own modal meaning, ironic expression as a means of expression, as well as an artistic-creative approach.

\section{REFERENCES}

1. Abdurahmanov H., Mahmudov N., Word aesthetics, Tashkent Uzbekistan USSR "Fan" publishing house, 1981. p. 38-39

2. Boboev T., "Fundamentals of Literary Criticism" Tashkent ר- "Uzbekistan" 2002. P.353

3. Hojiev A., "Explanatory dictionary of linguistic terms" Tashkent: National Encyclopedia of Uzbekistan, 2002. P.63

4. Rahmon Sh., Eternity: Poems - Tashkent: "Movarounnahr", 2012.
5. Yuldashev M., Literary text and the bases of its linguopoetic analysis. Tashkent: Fan, 2006. p.47

6. Mamajonov A., Stylistics of compound speech. Tashkent Uzbekistan USSR "Fan" publishing house 1990

7. Hakimov M., Fundamentals of Uzbek pragmalinguistics - Tashkent: Akadem edition, 2013. 